way in the world so as to concentrate the foundation's energies on new projects. The Max-Planck-Gesellschaft seems to have been especially influential in this decision but observers (not all journalists) wonder why the foundation should discard the feathers in its cap, especially when its members are unready to turn their enthusiasm for innovations into cash.

None of this seems to have prevented the assembly last week from pushing ahead with other plans. Byzantine and Chinese studies flourish, and the deep seismic sounding project known as the European Geotraverse has begun well. (There are even plans to interest the Soviet Union in the inclusion of the Kola Peninsula.) The foundation is also helping geophysicists to press their claims for a fair crack of the whip in the launching of European satellites, its long-standing interest in polymer science has led to the planned formation of a European Polymer Foundation, and the foundation programme of fellowships in toxicology has spawned an agreement with the European Commission for a study of the toxicology of chlorophenol chloropropenes designed to provide Brussels with a scientific basis for regulation, and intended by both parties as a proving ground for Community regulations.

The formation of a consortium to allow the foundation's smaller member states to take part in the continuation of the US Deep Sea Drilling Project due to begin next October is more of a scramble. Professor $R$. van Lieshout, director of the Netherlands science research council (ZWO) and organizer of the consortium, explained that the rush stems from the late decision on the future of the deep-sea drilling in the United States. But now "the train as already left the station".

There seems no prospect that the smaller members of the foundation will be able to raise the $\$ 2.5$ million a year required of full members, so that hopes turn on whether Britain will opt for full participation (a decision still to be made by the UK Natural Environment Research Council), as France and West Germany have already done. One parsimonious solution canvassed last week is that the smaller members might club together to pay the $\$ 200,000$ needed for the first year's membership, thus influencing the programme, but then decide to pull out. Final bids will be disclosed at a meeting in Zurich early in December.

For the rest, the assembly approved the launching of a project on forest ecosystems after (and in spite of) an impassioned speech by Professor W. Bossard, director of the Swiss Federal Institute of Forestry Research, threatening catastrophe for alpine valleys from avalanches and soil erosion if forest die-back were allowed to continue. The assembly also elected Professor van Lieshout and Professor T.D. Spearman (Trinity College, Dublin) as vice-presidents for the next three years.

John Maddox

\title{
UK research staff Too many dead-end jobs?
}

THE conditions of employment of British university research workers, many of whom are engaged on short-term contracts, represent the "unacceptable face of the high-tech revolution", a meeting of the Association of University Teachers (AUT) was told last week. Mr John Akker, deputy general secretary of the association, said that researchers' terms and conditions of employment were more like those of farm workers than of key workers in a vital industry.

AUT estimates there are 12,000 research staff employed in the universities, including those in research council units. Their contracts are normally attached to particular projects and may last anything from 3 months to 5 years. Almost all contract researchers, according to AUT, are required as a condition of their employment to sign a waiver clause denying them the right to claim unfair dismissal or to seek a redundancy payment. Dr B. Salter, who chaired an AUT advisory group on the subject, says that this clause contravenes the spirit of the relevant legislation, which was intended to apply to wellpaid short-term contracts. Researchers are paid less than lecturers and advance more slowly.

Because conditions of service and opportunities for advancement are unattractive, few contract researchers stay for long: in 1980,81 per cent had been researching for less than 5 years, although their academic qualifications were similar to or better than those of lecturers. Mr Akker last week described the treatment of researchers as a "wasteful and gross exploitation of talent". He said that the Prime Minister should examine the problem urgently if she wishes to increase output from science and technology.

The meeting, attended by 90 delegates representing all of Britain's universities, formally established a National Committee of Contract Researchers. The committee will hold local meetings throughout the country and will seek meetings with the University Grants Committee, the Committee of Vice-Chancellors and Principals and research councils, as well as government. AUT intends to make full use of legal sanctions where these are applicable and may consider demonstrative action.

The main aim is to establish a recognized career structure. AUT will ask universities to consider the establishment of "bridging pools" to pay researchers between projects, funded by means of a surcharge on research contracts. But AUT also wants to see other improvements in researchers' terms of service.

It was pointed out last week that many lecturers, on accepting early retirement, receive golden handshakes of $£ 20,000$ or more. A researcher of the same age would receive nothing.
Dr Salter, who is now a member of the contract researchers' committee, is under no illusions about the difficulty of the task AUT faces. One problem is that responsibilities are fragmented: most researchers are paid by universities, which in turn receive grants from research councils. Neither will tackle the problem without the other, says Salter. Another difficulty is that a young research population is often thought to be a good source of fresh ideas. Salter dismisses this notion, and argues that the same might be said of any profession.

Tim Beardsley

\section{Developing academy}

Professor Abdus Salam, the Pakistani physicist and champion of Third World scientists, is to be president of a "ThirdWord academy" of leading scientists in and from the developing world, it was announced last Friday at a ceremony in Trieste, Italy. The academy - which, says Salam, "will be happy to advise governments and other bodies" on matters of science and development - begins with 25 full fellows, two of them Nobel Prize winners, chosen from the existing fellowships of prestigious academies including the US National Academy of Sciences, and 14

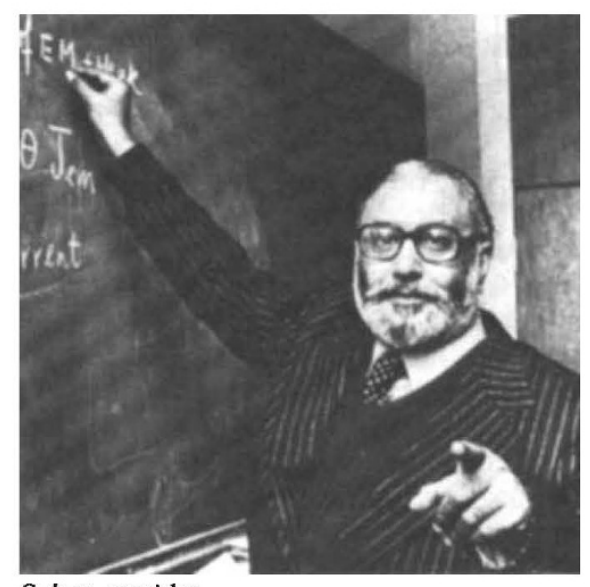

\section{Salam presides}

associate fellows. The associates are exnationals of developing countries now working in the West.

The academy will have four main roles, Salam said last week: to support "good men' in developing countries; to advise; to publish a newsletter on scientific issues in the Third World (to be edited in Caracas); and to promote "South-South" collaboration in science.

The academy will be "a collection of individuals", and thus a totally different exercise from the UN University, which Salam condemns as too bureaucratic. However, the new academy has as yet no budget. Salam sees himself doing a lot of the planning and writing of letters. The money will come, he says. Robert Walgate 